\title{
Pengaruh Penempatan Kerja dan Budaya Kerja Terhadap Kinerja Karyawan pada Hotel Adi Asri Pemuteran
}

\author{
Fathur Rizqi Samawi ${ }^{1}$, Wayan Cipta $^{2}$ \\ ${ }^{1}$ Universitas Pendidikan Ganesha, Indonesia \\ e-mail: fathurrizqisamawi@gmail.com, wayan.cipta@undiksha.ac.id
}

\begin{abstract}
Abstrak
Penelitian ini bertujuan untuk mengetahui pengaruh penempatan kerja dan budaya kerja terhadap kinerja karyawan di Hotel Adi Asri Pemuteran baik secara simultan maupun parsial. Rancangan penelitian yang digunakan dalam penelitian ini adalah kuantitatif kausal. Subjek dalam penelitian ini merupakan karyawan Hotel Adi Asri Pemuteran sedangkan objek penelitian ini adalah penempatan kerja, budaya kerja dan kinerja karyawan. Populasi penelitian yang digunakan berjumlah 46 orang karyawan. Data yang didapatkan dari hasil kuisioner dan wawancara kemudian dianalisis menggunakan analisis jalur (path analysis). Hasil penelitian ini menunjukkan (1) penempatan kerja dan budaya kerja berpengaruh positif terhadap kinerja karyawan, (2) penempatan kerja berpengaruh positif terhadap budaya kerja karyawan, (3) penempatan kerja berpengaruh positif terhadap kinerja karyawan, dan (4) budaya kerja berpengaruh positif terhadap kinerja karyawan.
\end{abstract}

Kata kunci: budaya kerja, kinerja karyawan, penempatan kerja.

\begin{abstract}
This research aims to determine the partial and simultan effects of work placement and work culture on employee performance at Adi Asri Hotel Pemuteran. The research design used in this research was a quantitative causal. The subjects in this study were employees of Adi Asri Hotel Pemuteran, while the objects of this study were job placement, work culture and employee performance. The research population used was 46 employees. The data obtained from the results of questionnaires and interviews were then analyzed using path analysis. The results of this study indicate (1) job placement and work culture have a positive effect on employee performance, (2) job placement has a positive effect on employee work culture, (3) work placement has a positive effect on employee performance, and (4) work culture has a positive effect on employee performance.
\end{abstract}

Keywords: employee performance, job placement, work culture. 


\section{PENDAHULUAN}

Setiap perusahaan dalam melakukan aktivitas pasti memiliki tujuan yang hendak dicapai, untuk mencapai atau mewujudkan tujuan tersebut setiap perusahaan harus pandai dalam memilih strategi, terutama dalam perencanaan sumber daya manusia yang pada intinya adalah terfokus pada langkah-langkah tertentu yang diambil oleh manajemen. Untuk mencapai tujuan perusahaan maka diperlukan karyawan yang memenuhi standar yang baik secara kuantitas maupun kualitasnya. Baik dalam kuantitas, artinya jumlah karyawan harus sesuai dengan kebutuhan pekerjaan pada satu bagian dalam perusahaan tersebut. Sedangkan baik dalam kualitas, maksudnya adalah mutu dari hasil kerja dari karyawan tersebut benar-benar dapat diandalkan sesuai dengan bidang yang ditekuninya.

Proses penempatan pegawai yang tidak tepat akan menyebabkan kinerja yang kurang optimal (Naliebrata, 2007). Menurut hasil penelitian yang dilakukan oleh Efendy (2017) bahwa penempatan kerja berpengaruh signifikan terhadap kinerja karyawan. Kinerja merupakan gambaran tingkat keberhasilan atau kegagalan pelaksanaan tugas pokok dan fungsi organisasi dalam mewujudkan sasaran, tujuan, misi dan visi organisasi. Dalam menentukan kinerja karyawan, perusahaan harus memiliki beberapa komponen yang menjadi alat ukur kinerja, antara lain: kualitas pekerjaan, kejujuran karyawan, inisiatif, kehadiran, sikap, kerjasama, keandalan, pengetahuan tentang pekerjaan, tanggung jawab dan pemanfaatan waktu kerja. Disamping itu juga harus didukung oleh budaya kerja didalam perusahaan yang mempunyai nilai-nilai dan norma-norma yang disepakati dan menjadi sebuah sikap dan perilaku karyawan dalam melaksanakan pekerjaan sehari-hari yang berlangsung secara terus-menerus hingga menjadi suatu kebiasaan yang pada akhirnya akan membentuk karakter seorang karyawan dalam menangani setiap pekerjaannya agar tujuan perusahaan tercapai.

Bali menjadi salah satu daerah tujuan wisata, berkembangnya industri pariwisata yang marak termasuk di Bali Utara adalah hotel. Berkembangnya industri pariwisata yang marak di Bali Utara menjadi salah satu daerah tujuan wisata. Hotel Adi Asri Pemuteran merupakan industri yang bergerak di bidang jasa pelayanan penginapan, penyediaan makanan dan minuman serta fasilitas lainnya. Dimana semua fasilitas itu diperuntukan bagi masyarakat umum, komponen-komponen perusahaan terutama sumber daya manusia yang terdapat di dalamnya sangat mempengaruhi pelaksanaan operasional perusahaan.

Kurangnya pemahaman dalam melakukan suatu pekerjaan akan berdampak pada pelaksanaan tugas karyawan di perusahaan. Masih banyak terjadi kurangnya koordinasi antar divisi yang mengakibatkan suatu pekerjaan tidak optimal. Hal tersebut mengindikasikan adanya permasalahan dalam kompetensi karyawan (Mustofa, 2016). Rendahnya kompetensi dapat dibuktikan dengan pendidikan formal terakhir yang pernah ditempuh karyawan. Adanya karyawan yang kompetensinya tidak sesuai dengan kualifikasi tingkat pendidikan yang dibutuhkan perusahaan dengan enam tingkat pendidikan terakhir dari karyawan mengindikasikan bahwa adanya masalah dalam kompetensi (Yunita et al., 2016).

Berdasarkan data yang diperoleh dari observasi awal di hotel Adi Asri Pemuteran terdapat banyak karyawan yang belum memenuhi standar kinerja per karyawan yang telah di tetapkan oleh perusahaan, sehingga baik tidaknya kinerja karyawan dapat dilihat dari pencapaian kinerja yang mampu diraih oleh karyawan tersebut. Dari sembilan orang karyawan, sebagian besar belum mencapai standar kinerja yang telah ditetapkan oleh perusahaan. Banyak faktor yang dapat mempengaruhi kinerja seorang karyawan dalam suatu perusahaan. Rendahnya kinerja karyawan dikarenakan karyawan yang penempatannya tidak sesuai dengan yang dibutuhkan Hotel Adi Asri Pemuteran, selain itu hal yang menyebabkan rendahnya kinerja karyawan adalah standar pendidikan dan pengembangan karir yang berjalan lambat.

Pengembangan Karir yang ada di Hotel Adi Asri Pemuteran berada pada kategori lambat, karena karyawan telah memiliki masa kerja 6-10 tahun. Padahal pada umumnya karyawan bisa naik jabatan lebih tinggi dalam jangka waktu 5 tahun dengan adanya rekomendasi dari kepala departemen bagian. Hal itu berarti karyawan akan membutuhkan waktu dan biaya yang lebih untuk menyelesaikan pekerjaan mereka. Seharusnya hal tersebut dapat dihindari jika setiap 
karyawan maupun manajemen memahami pekerjaan yang harus dilaksanakan pada setiap tugasnya, sehingga tujuan perusahaan dapat tercapai. Berdasarkan uraian latar belakang masalah diatas, maka peneliti memandang perlu dilakukan penelitian dengan judul Pengaruh Penempatan Kerja dan Budaya Kerja Terhadap Kinerja Karyawan pada Hotel Adi Asri Pemuteran.

\section{KAJIAN PUSTAKA DAN PERUMUSAN HIPOTESIS Hubungan Penempatan Kerja Dan Budaya Kerja Terhadap Kinerja Karyawan}

Ukuran kinerja menurut Michell (2008; 20), dapat dilihat dari empat hal, yaitu: (1) kualitas kerja, (2) ketetapan waktu dalam menyelesaikan pekerjaan, (3) kemampuan menyelesaikan pekerjaan, dan (4) kemampuan dalam membina kerjasama/komunikasi dengan pihak lain. Teori ini didukung hasil penelitian dari Devy (2017), yang menyatakan bahwa penempatan kerja dan budaya kerja berpengaruh positif terhadap kinerja karyawan.

$\mathrm{H}_{1}$ : Ada pengaruh penempatan kerja dan budaya kerja terhadap kinerja karyawan pada Hotel Adi Asri Pemuteran.

\section{Hubungan Penempatan Kerja Terhadap Budaya Kerja}

Menurut Bangun (2012) menyatakan bahwa jika karyawan tidak ditempatkan sesuai dengan kompetensi yang dimiliki maka hal terdebut akan mempengaruhi budaya kerja yang diterapkan dalam organisasi. Pendapat tersebut diatas didukung oleh Devy (2017) yang menyatakan ada pengaruh positif dari penempatan kerja terhadap budaya kerja.

$\mathrm{H}_{2:}$ Ada pengaruh penempatan kerja terhadap budaya kerja di Hotel Adi Asri Pemuteran

\section{Hubungan Penempatan Kerja Terhadap Kinerja Karyawan}

Penempatan karyawan dengan kinerja karyawan mempunyai hubungan yang erat. Mangkunegara, (2011; 67) mengatakan bahwa istilah kinerja berasal dari kata Job Performance atau Actual Performance (prestasi kerja atau prestasi sesungguhnya yang dicapai oleh seseorang). Wibowo (2007), kinerja mempunyai makna yang lebih luas bukan hanya hasil kerja, tetapi termasuk bagaimana proses pekerjaan berlangsung. Pemuteran.

$\mathrm{H}_{3:}$ Ada pengaruh penempatan kerja terhadap kinerja karyawan di Hotel Adi Asri

\section{Hubungan Budaya Kerja Terhadap Kinerja Karyawan}

Moeljono (2005; 2), mengemukakan bahwa budaya kerja pada umumnya merupakan pernyataan filosofis yang dapat difungsikan sebagai tuntutan yang mengikat pada karyawan karena dapat diformulasikan secara formal, dalam berbagai peraturan dan ketentuan perusahaan

$\mathrm{H}_{4}$ : Ada pengaruh budaya kerja terhadap kinerja karyawan pada Hotel Adi Asri Pemuteran.

\section{METODOLOGI}

Penelitian ini dilakukan pada Hotel Adi Asri Pemuteran. Rancangan penelitian yang digunakan dalam penelitian ini adalah kuantitatif kausal. Dalam penelitian ini penempatan kerja dan budaya kerja dijadikan sebagai variabel bebas serta kinerja karyawan sebagai variabel terikat. Subjek dalam penelitian ini adalah karyawan Hotel Adi Asri Pemuteran dan objeknya yaitu penempatan kerja, budaya kerja serta kinerja karyawan pada Hotel Adi Asri Pemuteran. Populasi dalam penelitian ini adalah karyawan Hotel Adi Asri Pemuteran yang berjumlah 46 orang karyawan.

Dalam penelitian ini terdapat dua jenis data menurut sifatnya yaitu: (1) kualitatif adalah data yang tidak berbentuk angka. Data yang didapat berupa latar belakang sejarah organisasi, struktur organisasi dan data lain yang diambil dari data organisasi. (2) kuantitatif adalah data yang berbentuk angka. Data yang dipakai dalam penelitian ini yaitu standar kinerja dan pencapaian kerja serta tingkat hunian hotel. Sedangkan ditinjau dari sumbernya, data yang 
digunakan dalam penelitian ini yaitu (1) data primer yang berupa kuesioner awal penelitian budaya kerja, kuesioner tipe $A$ untuk atasan, dan kuesioner tipe B untuk karyawan. (2) data sekunder yang berupa hasil telaah data kuantitatif.

Teknik pengumpulan data yang digunakan dalam memperoleh data penelitian adalah: (1) teknik Kuesioner. Data yang diperoleh yaitu data tanggapan karyawan terhadap penempatan kerja, budaya kerja, dan kinerja karyawan. (2) wawancara. Berfungsi sebagai metode pelengkap untuk mendapat informasi secara lisan dengan tujuan agar mendapatkan data untuk menjelaskan permasalahan, wawancara dilakukan langsung dengan pimpinan dan beberapa karyawan Hotel Adi Asri Pemuteran.

Instrumen penelitian yang digunakan dalam penelitian ini adalah kuesioner yang berisi daftar pertanyaan yang disebar kepada responden dan wawancara sebagai instrumen pengumpulan data dalam bentuk pedoman wawancara. Terdapat dua uji yang dilakukan dalam instrumen penelitian yaitu: (1) pengujian validitas instrumen, (2) pengujian reliabilitas instrumen.

Analisis data dalam penelitian ini menggunakan analisis jalur (path analysis), yaitu analisis yang digunakan untuk menganalisis pola hubungan yang tidak langsung. Analisis jalur adalah suatu teknik untuk menganalisis hubungan sebab akibat yang terjadi pada regresi berganda jika variabel bebasnya mempengaruhi variabel terikat tidak hanya secara langsung tetapi juga secara tidak langsung (Rutherford, 1993).

\section{HASIL DAN PEMBAHASAN} Hasil

Hasil penelitian dilakukan dengan meenggunakan metode analisis jalur untuk mengetahui pengaruh pada penempatan kerja dan budaya kerja terhadap kinerja karyawan Hotel Adi Asri Pemuteran, populasi penelitian menggunakan 46 karyawan. Perhitungan uji statistik analisis jalur menggunakan bantuan Program SPSS 23.0 For Windows. Berdasarkan hasil analisis jalur Pengaruh Penempatan Kerja $\left(X_{1}\right)$ dan Budaya Kerja $\left(X_{2}\right)$ Terhadap Kinerja Karyawan $(Y)$ dapat simpulkan hubungan antar variabel sebagai berikut. Pertama, ada pengaruh dari penempatan kerja dan budaya kerja terhadap kinerja karyawan pada Hotel Adi Asri Pemuteran, hal tersebut ditunjukkan dengan nilai $p$-value $R^{2} \mathrm{yx}_{1} \mathrm{x}_{2}=0,000<$ alpha $(\alpha)=$ 0,05 . Besar pengaruh penempatan kerja dan budaya kerja terhadap kinerja karyawan adalah 0,843 . Hasil tersebut menunjukkan bahwa sebesar $84,30 \%$ kinerja karyawan dipengaruhi oleh variabel penempatan kerja dan budaya kerja dengan besar sumbangan pengaruh penempatan kerja dan budaya kerja terhadap kinerja karyawan sebesar $71,10 \%$, sedangkan $28,90 \%$ kinerja karyawan dipengaruh oleh variabel lain diluar variabel penempatan kerja dan budaya kerja. Kedua, ada pengaruh dari penempatan kerja terhadap budaya kerja pada Hotel Adi Asri Pemuteran, hal tersebut ditunjukkan dengan nilai $p$-value $\mathrm{Px}_{1} \mathrm{x}_{2}=0,000<$ alpha $(\alpha)=0,05$. Besar pengaruh penempatan kerja terhadap budaya kerja adalah 0,736. Hasil tersebut menunjukkan bahwa sebesar $73,60 \%$ budaya kerja dipengaruhi oleh variabel penempatan kerja dengan besar sumbangan pengaruh penempatan kerja terhadap budaya kerja sebesar $54,20 \%$, sedangkan $26,4 \%$ budaya kerja dipengaruh oleh variabel lain diluar variabel penempatan kerja. Ketiga, ada pengaruh dari penempatan kerja terhadap kinerja karyawan pada Hotel Adi Asri Pemuteran, hal tersebut ditunjukkan dengan nilai $p$-value Pyx $_{1}=0,042<$ alpha $(\alpha)=0,05$. Besar pengaruh penempatan kerja terhadap kinerja karyawan adalah 0,305. Hasil tersebut menunjukkan bahwa sebesar 30,50\% kinerja karyawan dipengaruhi oleh variabel penempatan kerja dengan besar sumbangan pengaruh penempatan kerja terhadap kinerja karyawan sebesar 09,30\%. Keempat, ada pengaruh dari budaya kerja terhadap kinerja karyawan pada Hotel Adi Asri Pemuteran, hal tersebut ditunjukkan dengan nilai $p$-value $\mathrm{Pyx}_{2}=$ $0,000<$ alpha $(\alpha)=0,05$. Besar pengaruh budaya kerja terhadap kinerja karyawan adalah 0,627 . Hasil tersebut menunjukkan bahwa sebesar $62,70 \%$ kinerja karyawan dipengaruhi oleh variabel budaya kerja dengan besar sumbangan pengaruh budaya kerja terhadap kinerja karyawan sebesar $39,30 \%$. 


\section{Pembahasan}

Berdasarkan hasil penelitian variabel penempatan kerja dan budaya kerja menunjukkan bahwa kinerja karyawan pada Hotel Adi Asri Pemuteran dapat dipengaruhi oleh keduanya secara bersamaan. Hasil penelitian ini didukung dengan teori dari Siagian (2004) bahwa dengan penempatan yang tidak tepat dan budaya kerja yang rendah, kinerja seseorang tidak akan sesuai dengan harapan manajemen dan tuntutan organisasi, dengan demikian mereka menampilkan produktivitas kerja yang rendah sehingga dapat berakibat pada kejenuhan dan kebosanan. Teori ini juga sesuai dengan kajian empirik dari Devy (2017) yang menyatakan bahwa penempatan kerja dan budaya kerja berpengaruh positif terhadap kinerja karyawan.

Hasil penelitian selanjutnya menjelaskan bahwa penempatan kerja berpengaruh terhadap budaya kerja di Hotel Adi Asri Pemuteran. Menurut pendapat Bangun (2012) bahwa jika karyawan tidak ditempatkan sesuai dengan kompetensi yang dimiliki maka hal terdebut akan mempengaruhi budaya kerja yang diterapkan dalam organisasi. Adapun teori lainnya yang mendukung adalah kajian empirik dari Devy (2017) yang menyatakan ada pengaruh positif dari penempatan kerja terhadap budaya kerja. Hasil penelitian ini sesuai dengan dua teori para ahli tersebut, dan dapat disimpulkan dari peryataan tersebut bahwa penempatan kerja berpengaruh terhadap budaya kerja.

Penelitian selanjutnya menunjukkan hasil bahwa penempatan kerja berpengaruh terhadap kinerja karyawan di Hotel Adi Asri Pemuteran. Menurut pendapat dari Naliebrata (2007) menyatakan bahwa proses penempatan pegawai yang tidak tepat akan nyebabkan kinerja yang kurang optimal. Teori ini juga didukung dengan kajian empirik dari Efendy (2017) yang menyebutkan bahwa penempatan kerja memiliki pengaruh positif terhadap kinerja karyawan.

Hasil penelitian selanjutnya menunjukkan adanya pengaruh budaya kerja terhadap kinerja karyawan di Hotel Adi Asri Pemuteran. Hasil penelitian tersebut sesuai dengan hasil penelitian Arianto (2013) yang menunjukkan budaya kerja bepengaruh positif terhadap kinerja. Hasil penelitian ini juga didukung oleh Ardana et al. (2012), yang menyatakan bahwa bila karyawan mempunyai budaya kerja yang tinggi maka secara kesinambungan kinerja karyawan dapat lebih terjamin dari waktu ke waktu.

\section{SIMPULAN DAN SARAN Simpulan}

Berdasarkan populasi penelitian dari 46 orang karyawan Hotel Adi Asri Pemuteran dapat ditarik kesimpulan sebagai berikut. Pertama, penempatan kerja dan budaya kerja berpengaruh positif terhadap kinerja karyawan. Kedua, penempatan kerja berpengaruh positif terhadap budaya kerja karyawan. Ketiga, penempatan kerja berpengaruh positif terhadap kinerja karyawan. Keempat, budaya kerja berpengaruh positif terhadap kinerja karyawan.

\section{Saran}

Berdasarkan simpulan diatas, saran yang diajukan adalah sebagai berikut. Pertama, Perusahan Hotel Adi Asri Pemuteran diharapkan bisa meningkatkan kinerja karyawan dengan cara menempatkan karyawan secara tepat, misalnya dengan menempatkan karyawan sesuai dengan bidang keahlian, keilmuan, masa jabatan dan usia, dengan demikian karyawan bisa bekerja lebih baik dan efektif dengan kondisi yang sesuai. Selain penempatan kerja, perusahaan juga harus memperhatikan budaya kerja yang ada di lingkungan kerja, misalnya menerapkan visi dan misi yang sesuai denga tujuan perusahaan, juga perlu adanya komunikasi dengan semua karyawan mengenai apa saja hal yang perlu diterapkan untuk mengembangkan standar sikap yang harus dilakukan. Kedua, bagi peneliti selanjutnya yang tertarik untuk melanjutkan penelitian mengenai penempatan kerja, budaya kerja serta kinerja karyawan diharapkan untuk mengembangkan penelitian ini dengan menggunakan populasi dan sampel yang lebih luas, sehingga hasil penelitian yang didapat lebih lengkap, dan menggunakan variabel lain yang dapat mempengaruhi kinerja karyawan. 


\section{Daftar Pustaka}

Ardana, I. K., Mujiati, N., \& Utama, I. (2012). Manajemen Sumber Daya Manusia. Graha IImu.

Arianto, D. A. N. (2013). Pengaruh Kedisiplinan, Lingkungan Kerja dan Budaya Kerja Terhadap Kinerja Tenaga Pengajar. Jurnal Ekonomi, 9(2).

Bangun, W. (2012). Manajemen Sumber Daya Manusia. Erlangga.

Devy, P. A. D. S. (2017). Pengaruh Penempatan Kerja dan Budaya Kerja Terhadap Kinerja Karyawan Pada CV Prabu Tirta Gunung Negara Tahun 2016. Universitas Pendidikan Ganesha.

Efendy, E. S. (2017). Pengaruh Penempatan Kerja Terhadap Kinerja Pegawai Pada Kantor Kejaksaan Negeri Kendari. Sekripsi Manajemen Universitas Halu Oleo. Mahirot, Tua Efendi Hariandja. 2009. Manajemen Sumber Daya Manusia, Pengadaan, Pengembangan, Pengo. Grafindo.

Mangkunegara, A. A. A. P. (2011). Manajemen Sumber Daya Manusia. PT. Remaja Rosdakarya.

Michell. (2008). Human Resource Management: The Strategic Prespective. Herper Collins College Publishers.

Moeljono, D. (2005). Budaya Korporat dan Keunggulan Korporasi. PT. Elex Media Komunikasi.

Mustofa. (2016). Pengaruh Penempatan dan Komunikasi Terhadap Kinerja Karyawan. Jurnal Ekonomi Manajemen, 2(2).

Naliebrata, A. (2007). Analisis Pengaruh Penempatan Pegawai Berbasis Kompetensi Terhadap Kinerja Pegawai. Universitas Saburai Bandar Lampung.

Rutherford, R. D. (1993). Statistical Model for Causal Analysis. John Wiley \& Sons Inc.

Siagian. (2004). Pengaruh Kompetensi, Budaya Kerja dan Kepuasan Kerja Terhadap Kinerja Pegawai. Universitas Islam Negeri Sultan Syarif Kasim.

Wibowo. (2007). Manajemen Kinerja. Rajawali Pers.

Yunita, K. E., Yulianthini, N. N., \& Bagia, I. W. (2016). Pengaruh Pengalaman Kerja dan Penempatan Karyawan Terhadap Kinerja Karyawan Pada Bali. Bisma, 4. https://ejournal.undiksha.ac.id/index.php/JMI/article/download/6714/4575 